\title{
Feldstein-Horioka puzzle for a panel of 14 CEE countries: Empirical evidence
}

\author{
Dushko Josheski（ $\underline{\text { dusko.josevski@ugd.edu.mk) }}$ \\ Teaching assistant for the field applied economics at University Goce Delcev-Stip \\ Darko Lazarov (․arko.lazarov@ugd.edu.mk) \\ Teaching assistant for the field economic theory University Goce Delcev-Stip
}

\begin{abstract}
In this paper we investigate Feldstein Horioka puzzle for 14 CEE countries (Albania, Bosnia and Herzegovina, Bulgaria, Croatia, Greece, Hungary, Kosovo, Latvia, Lithuania, Macedonia, Estonia,Poland,Romania,Serbia). In our paper when we investigate the whole sample fo 14 CEE countries we find less positive association between investment and savings meaning that capital is highly mobile. While when we regress the subsample of those countries from the sample which are EU members we find the lowest coeffcient of association between investment and saving therefore capital is highly mobile in those countries. While in the Non-EU members from this CEE countires the coeficient is highest 0.13 ,meaning there is lowest capital mobility. Unit root tests proved that in this sample of countries savings are $\mathrm{I}(1)$ or $\mathrm{I}(2)$ process, and investments are stationary.
\end{abstract}

Keywords:Investment savings correlation, stationarity, capital mobility,macroeconomic puzzles 


\section{Introduction}

A well known stylized fact in international macroeconomics is the high correlation between domestic savings and investment in major industrial countries. ${ }^{1}$ Feldstein and Horioka's (1980) seminal work, they interpret this high savings-investment correlation as an indicator of capital immobility. This interpretation, however, poses an uncomfortable puzzle ${ }^{2}$, the so-called Feldstein-Horioka (hereafter FH) puzzle, as the conventional wisdom in the field of international macroeconomics is that the rich countries have a high degree of capital mobility. The literature on Fedlstein Horioka puzzle is extenzive the original FH article has been cited 142 times $^{3}$ between 1988 and 1995. From the CA identity:

$$
C A_{t}=S_{t}-I_{t}=- \text { FinancialAccount }_{t} \Rightarrow I_{t}=F A_{t}+S_{t}
$$

FH argued that if there is perfect $\mathrm{K}$ mobility, we should observe low correlation between domestic I and S. Investors in one country do not need the funds from domestic savers and can borrow from international markets at world rates. By the same token, savers can lend to foreign investor the entirety of the domestic savings. This concept related to long-term real capital flows. Frankel (1995) came up with the distinction between this measure of capital mobility and the financial capital flows measured by real interest party, covered and uncovered interest parities.

F-H estimated:

$$
\frac{I_{t}}{Y_{t}}=\alpha+\beta \frac{S_{t}}{Y_{t}}+u_{t} \text { for each country }
$$

With perfect capital mobility, the null hypothesis is that the slope coefficient would be zero for small open economies. For large economies the slope coefficient would be larger than zero. For the small economy result to hold, we would also need $\operatorname{Corr}\left(\mathrm{r}^{*}, \mathrm{~S}\right)=0$, interest parity must hold $\left(\mathrm{r}=\mathrm{r}^{*}\right)$ and $\operatorname{corr}(\mathrm{S}, \mathrm{u})=0$. In the next section will review empirical literature on this topic.

\footnotetext{
${ }^{1}$ See, for example, Feldstein and Horioka (1980), Feldstein (1983), Penati and Dooley (1984), Dooley et al (1987), Obstfeld (1986), Frankel et al (1986), Tesar (1991), Feldstein and Bachetta (1991).

${ }^{2}$ Since the conventional wisdom in most exchange rate and open-economy macroeconomic models was that capital mobility was high.

${ }^{3}$ Coakley,Farida Kulasi, and Ron Smith(1998), The Feldstein-Horioka Puzzle and Capital Mobility: A Review, International Journal of Finance and Economics Int. J. Fin. Econ. 3: 169-188 (1998)
} 


\section{Empirical literature review}

Existing empirical studies on the savings-investment relationship can be split into two broad groups according to their estimation methodologies. The first group takes a non-time-series approach. The second group uses time series techniques. In the next table we present some of the most important studies.

\begin{tabular}{|c|c|c|}
\hline Study & Technique & Main findings \\
\hline Feldstein Horioka(1980) & cross-section regressions & $\begin{array}{l}\text { the two ratios(savings and } \\
\text { investment) are highly correlated }\end{array}$ \\
\hline Krol (1996) & $\begin{array}{l}\text { pooled data of } 21 \text { OECD } \\
\text { countries }\end{array}$ & $\begin{array}{l}\text { an estimated coefficient of } 0.2 \text {, } \\
\text { which is significantly smaller than } \\
\text { the cross-section estimates reported } \\
\text { in earlier studies }\end{array}$ \\
\hline Miller (1988) & Time series techniques & $\begin{array}{l}\text { He finds that the two series are } \\
\text { cointegrated under the fixed } \\
\text { exchange rate regime but not under } \\
\text { the flexible exchange rate regime }\end{array}$ \\
\hline $\begin{array}{l}\text { Jansen (1996) and Coakley and } \\
\text { Kulasi (1997) }\end{array}$ & Time series techniques & $\begin{array}{l}\text { also show a positive long-run } \\
\text { equilibrium relationship between } \\
\text { saving and investment in OECD } \\
\text { countries. }\end{array}$ \\
\hline Coiteux and Olivierar (2000) & $\begin{array}{l}\text { a panel cointegration } \\
\text { technique }\end{array}$ & $\begin{array}{l}\text { long-run saving-investment } \\
\text { correlation of } 0.6 \text { in } 21 \text { OECD } \\
\text { countries }\end{array}$ \\
\hline Caporale et al. (2005) & $\begin{array}{l}\text { a variety of asymptotically } \\
\text { efficient cointegration } \\
\text { estimators to test the } \\
\text { hypothesis of a unit retention } \\
\text { coefficient }\end{array}$ & $\begin{array}{l}\text { they find sample evidence of the FH } \\
\text { puzzle }\end{array}$ \\
\hline Sarno and Taylor (1998) & $\begin{array}{l}\text { Blanchard and Quah } \\
\text { decomposition }\end{array}$ & $\begin{array}{l}\text { They show that the short-run } \\
\text { correlation is significantly higher } \\
\text { than the long-run correlation. }\end{array}$ \\
\hline
\end{tabular}

Source: Grier, Lin, Ye (2008) ${ }^{4}$

\footnotetext{
${ }^{4}$ Kevin Grier, Shu Lin.Haichun Ye,(2008), Savings and Investment in the USA: Solving the Feldstein Horioka Puzzle, University of Colorado Denver
} 


\section{Data and methodology used in this paper}

The data are collected from the World Bank data site ${ }^{5}$. Data are for 14 countries. We investigate Feldstein Horioka puzzle for 14 CEE countries (Albania, Bosnia and Herzegovina, Bulgaria, Croatia, Greece, Hungary, Kosovo, Latvia, Lithuania, Macedonia, Estonia, Poland, Romania, Serbia).Variables of interest here are: Domestic investment to GDP, Domestic savings to GDP, Current account balance, and income per capita. Definitions are given in Appendix 1. Descriptive statistics is presented in Table 1.From the six plots in Appendix 0 we can see that savings and investment are I (1) variables and heteroscedasticity and normality is not a problem.

\section{Table 1 Descriptive statistics of the model ${ }^{6}$}

\begin{tabular}{|l|c|c|c|c|c|}
\hline Variables & Observations & Mean & $\begin{array}{c}\text { Std. } \\
\text { Dev. }\end{array}$ & Minimum & Maximum \\
\hline $\begin{array}{l}\text { Current account } \\
\text { balance }\end{array}$ & 283 & -6.8354 & 5.08295 & -27.16 & 9.33 \\
\hline $\begin{array}{l}\text { Domestic investment } \\
\text { to GDP }\end{array}$ & 283 & 21.3767 & 5.0348 & 5.2 & 35.99 \\
\hline $\begin{array}{l}\text { Domestic savings to } \\
\text { GDP }\end{array}$ & 283 & 10.7553 & 14.3818 & -71.82 & 48.11 \\
\hline $\begin{array}{l}\text { credit spread(real } \\
\text { interest rates } \\
\text { difference) }\end{array}$ & 283 & 106.177 & 56.8535 & 1 & 204 \\
\hline income per capita & 283 & 127.859 & 71.9734 & 1 & 251 \\
\hline
\end{tabular}

From the table we can see that domestic savings constitutes on average $10.75 \%$ of GDP, while domestic investment is $21.37 \%$ of GDP. Current account Balance on average is negative -6.8354 of GDP. In the tables is given also the descriptive statistics for the credit spread and income per capita. In the following Table 2 we present the results from the Feldstein Horioka equation. F-H model is presented with the following regression:

Feldstein-Horioka regression: $\quad(I / G D P=\alpha+\beta(N S / G D P)+v$

Feldstein (1980) argued that if capital were perfectly mobile, he would find $\beta=0$. Instead, $\beta$ was much closer to 1.The coefficient ("saving retention") fell a bit subsequently, but still high. Three "puzzles", if the saving -investment coefficient is to be measured as a measure of barriers to international financial integration:

\footnotetext{
${ }^{5}$ http://search.worldbank.org/data?qterm=\&language=EN\&format $=$

${ }^{6}$ See Also Appendix 0 six plots for variables of interest Domestic savings and Domestic investment
} 
1. The coefficient is statistically far above zero (the original Feldstein- Horioka finding),

2. it is even higher for industrialized than for developing countries, and

3. There is little observed tendency for it to decline over time.

Table 2 Feldstein -Horioka coefficients and real interest rate volatility

\begin{tabular}{|l|l|c|c|c|}
\hline Number & \multicolumn{1}{|c|}{ country } & $\begin{array}{c}\text { F-H } \\
\text { coefficient }\end{array}$ & p-value & $\begin{array}{c}\text { real interest } \\
\text { rate } \\
\text { volatility }\end{array}$ \\
\hline $\mathbf{1}$ & Albania & $\mathbf{0 . 1 7 1 0 6 9 1}$ & 0.003 & $\mathbf{1 0 . 4 1 1 5}$ \\
\hline $\mathbf{2}$ & Bosnia and Herzegovina & $\mathbf{0 . 1 3 4 8 1 1 7}$ & 0.043 & $\mathbf{6 . 1 0 0 5 8}$ \\
\hline $\mathbf{3}$ & Bulgaria & $\mathbf{0 . 1 6 5 5 0 9 5}$ & 0.495 & $\mathbf{5 8 . 0 2 9}$ \\
\hline $\mathbf{4}$ & Croatia & $\mathbf{0 . 2 5 5 8 2 4 4}$ & 0.414 & $\mathbf{5 . 6 2 7 3 1}$ \\
\hline $\mathbf{5}$ & Estonia & $\mathbf{0 . 3 0 4 1 5 9 1}$ & 0.308 & $\mathbf{3 . 0 9 9 9}$ \\
\hline $\mathbf{6}$ & Greece & $\mathbf{- 1 . 1 6 3 6 2 3}$ & 0.096 & $\mathbf{1 . 9 0 0 7 6}$ \\
\hline $\mathbf{7}$ & Kosovo & $\mathbf{3 . 1 9 7 3 2 1}$ & 0.452 & $\mathbf{0 . 9 0 9 3 6}$ \\
\hline $\mathbf{8}$ & Macedonia, FYR & $\mathbf{- 0 . 2 5 6 7 3 3}$ & 0.306 & $\mathbf{9 . 3 5 1 3 2}$ \\
\hline $\mathbf{9}$ & Romania & $\mathbf{0 . 2 0 2 8 9 2 9}$ & 0.341 & $\mathbf{7 . 3 3 3 9 4}$ \\
\hline $\mathbf{1 0}$ & Latvia & $\mathbf{- 0 . 2 3 5 9 9 4}$ & 0.053 & $\mathbf{1 1 . 6 6 2 6}$ \\
\hline $\mathbf{1 1}$ & Lithuania & $\mathbf{0 . 4 7 3 0 7 4 7}$ & 0.136 & $\mathbf{3 . 1 0 6 3 3}$ \\
\hline $\mathbf{1 2}$ & Poland & $\mathbf{- 0 . 1 0 4 4 4 4}$ & 0.858 & $\mathbf{1 . 8 5 4 7 1}$ \\
\hline $\mathbf{1 3}$ & Serbia & $\mathbf{0 . 0 7 5 2 8 9 7}$ & 0.746 & $\mathbf{3 0 . 0 4 2 9}$ \\
\hline $\mathbf{1 4}$ & Hungary & $\mathbf{0 . 0 3 6 8 4 3 2}$ & 0.890 & $\mathbf{3 . 0 4 8 7 6}$ \\
\hline
\end{tabular}

Here it should be noted that even though we expect F-H coefficient ${ }^{8}$ to be between 0 and 1 , there are some deviations from this range, which implies that this model describes very simplified behaviour of savings and investment. P-value is probability of significance of this coefficient. Real interest rate volatility is the standard deviation of the interest rate spread. Regression we use here or the second model is:

$$
S D I R=\alpha+\beta F H+v
$$

Result is represented in the following aaplot

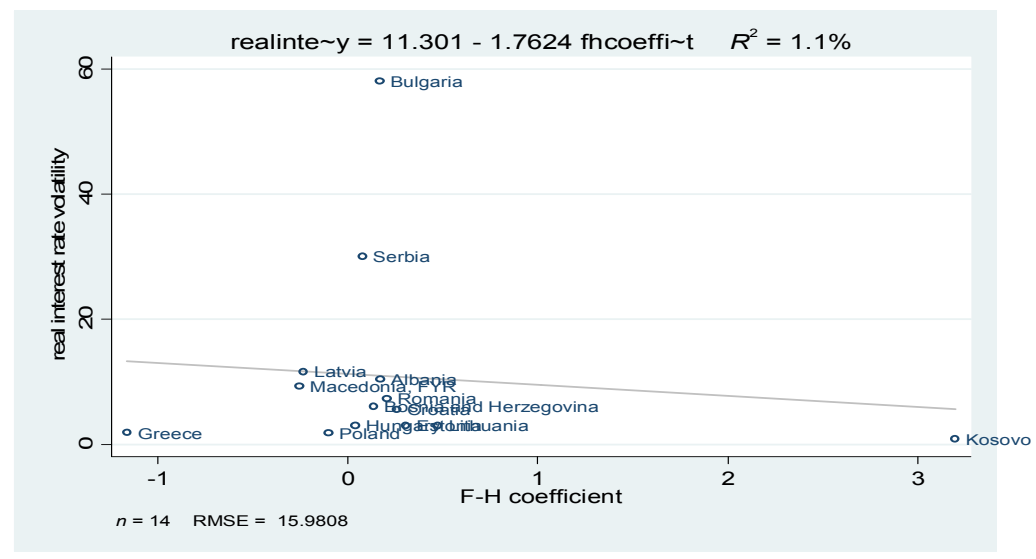

\footnotetext{
${ }^{7}$ Standard deviations of interest rate

${ }^{8}$ Feldstein Horioka coefficient measures capital mobility.The higher this coefficient is means that capital is less mobile in that country or countries, the lower this coefficient is it is interpreted as capital mobility.
} 
In our model higher F-H coefficient is associated with lower real interest rate volatility or vice versa. This implies that higher level of financial integration is not associated with higher volatility of interest rate spread. This is opposite for the Results presented in (Giang Lee, 2000) for instance for his paper on financial integration in Asian economies. From the table 2 we can see that standard deviations of interest rates are high. So in this period interest rates in CEE countries are highly volatile. They are more volatile than in the sample of Asian countries in (Giang Lee, 2000), but for the period 1976-1996. The small countries like CEE countries take anchor LIBOR or EURIBOR ${ }^{9}$, so it is likely that the source of fluctuations is in the outside economy than in the home country itself. On the next plot is presented the cross section OLS regression for the CEE countries. In the table 3 below graph is presented the result from the Panel regression. From the aaplot (scatter) we can see positive linear trend between domestic savings and investment ${ }^{10}$.

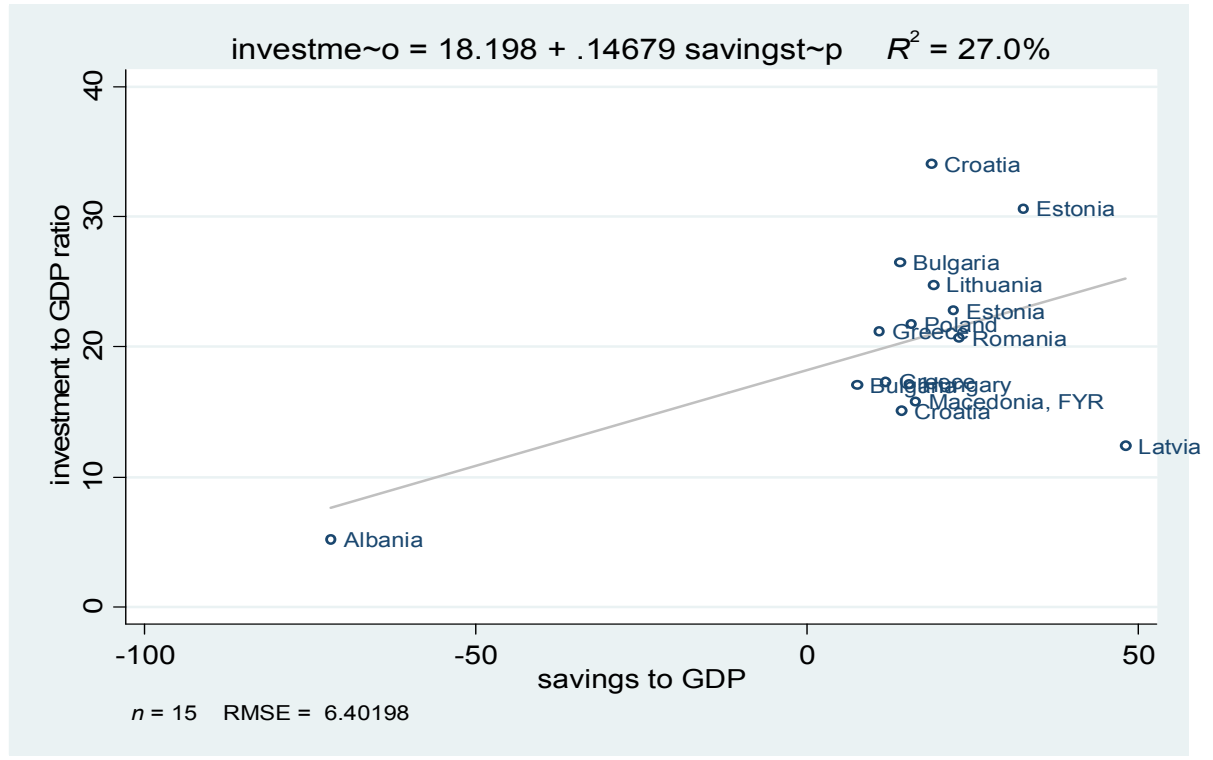

\footnotetext{
${ }^{9}$ Euribor and LIBOR are comparable base rates. Euribor is the average interbank interest rate at which European banks are prepared to lend to one another. LIBOR is the average interbank interest rate at which a selection of banks on the London money market are prepared to lend to one another. Just like Euribor, LIBOR comes in 15 different maturities. The main difference is that LIBOR rates come in 10 different currencies. We would like to refer to current LIBOR interest rates and background information on LIBOR, in case you are interested in additional information on LIBOR.

${ }^{10}$ See Appendix 3 Feldstein Horioka regression for every CEE country.
} 
Table 3 Panel regression results on the Feldstein Horioka model ${ }^{11}$

\begin{tabular}{|l|l|c|c|}
\hline Dependent variable & Domestic investment to GDP & Coef. & p-value \\
\hline \multirow{2}{*}{ Independent variables } & Domestic savings to GDP & 0.090869 & 0.000 \\
\cline { 2 - 4 } & Constant & 20.2719 & 0.000 \\
\hline Number of observations & \multicolumn{2}{|c|}{283} \\
\hline$R^{2}$ (between panels) & \multicolumn{2}{|c|}{0.4281} \\
\hline
\end{tabular}

In Appendix 3 are presented the results for each CEE countries for the Feldstein Horioka model. The F-H coefficient is of small size and very positive and statistically significant meaning that CEE countries are highly financially integrated.

\section{Unit root tests for the domestic savings and investment in CEE countries}

In the next table we summarize the results from the ADF test on the whole sample of countries for the domestic savings and investment variables.

Table 6 Augmented Dickey-Fuller tests for the whole sample of countries

\begin{tabular}{|c|c|c|}
\hline \multirow{2}{*}{$\begin{array}{c}\text { Augmented Dickey-Fuller } \\
\text { test }\end{array}$} & Domestic savings & domestic investment \\
\hline & $\begin{array}{l}\text { test statistic versus } \\
\text { critical value at } 95 \%\end{array}$ & $\begin{array}{c}\text { test statistic versus critical } \\
\text { value at } 95 \%\end{array}$ \\
\hline Albania & $\begin{array}{c}(-9.804>-3.000) \\
\text { stationary }\end{array}$ & $\begin{array}{c}(-3.380>-3.000) \\
\text { stationary }\end{array}$ \\
\hline Bosnia and Herzegovina & $\begin{array}{c}(-4.905>-3.750) \\
\mathrm{I}(2)\end{array}$ & $\begin{array}{l}(-3.960>3.750) \\
\text { stationary }\end{array}$ \\
\hline Bulgaria & $\begin{array}{c}(-6.853>-3.000) \\
I(2)\end{array}$ & $\begin{array}{c}(-4.494>-3.000) \\
\text { stationary }\end{array}$ \\
\hline Croatia & $\begin{array}{c}(-13.608>-3.000) \\
\mathrm{I}(2)\end{array}$ & $\begin{array}{c}(-8.029>-3.000) \\
\text { stationary }\end{array}$ \\
\hline Estonia & $\begin{array}{c}(-5.033>-3.000) \\
\mathrm{I}(1)\end{array}$ & $\begin{array}{c}(-4.679>-3.000) \\
\text { stationary }\end{array}$ \\
\hline Greece & $\begin{array}{c}(-4.217>-3.000) \\
\mathrm{I}(1)\end{array}$ & $\begin{array}{c}(-4.745>-3.000) \\
\text { stationary }\end{array}$ \\
\hline Kosovo & $\begin{array}{c}(-2.763<-3.000) \\
\text { non-stationary }\end{array}$ & $\begin{array}{c}(-5.530>-3.000) \\
\text { stationary }\end{array}$ \\
\hline Macedonia, FYR & $\begin{array}{c}(-3.690>-3.000) \\
\text { stationary }\end{array}$ & $\begin{array}{c}(-4.633>-3.000) \\
\text { stationary }\end{array}$ \\
\hline Romania & $\begin{array}{c}(-3.404>-3.000) \\
\mathrm{I}(1)\end{array}$ & $\begin{array}{c}(-4.668>-3.000) \\
\text { stationary }\end{array}$ \\
\hline Latvia & $\begin{array}{c}(-8.231>-3.000) \\
\text { stationary }\end{array}$ & $\begin{array}{c}(-4.668>-3.000) \\
\text { stationary }\end{array}$ \\
\hline
\end{tabular}

\footnotetext{
${ }^{11}$ See Appendix 2 Feldstein Horioka Panel regression
} 


\begin{tabular}{|c|c|c|}
\hline Lithuania & $\begin{array}{c}(-3.649>-3.000) \\
\text { stationary }\end{array}$ & $\begin{array}{c}(-4.351>-3.000) \\
\text { stationary }\end{array}$ \\
\hline Poland & $\begin{array}{c}(-3.404>-3.000) \\
\mathrm{I}(1)\end{array}$ & $\begin{array}{c}(-4.668>-3.000) \\
\text { stationary }\end{array}$ \\
\hline Serbia & $\begin{array}{c}(-3.563>-3.000) \\
\mathrm{I}(1)\end{array}$ & $\begin{array}{c}(-7.212>-3.000) \\
\text { stationary }\end{array}$ \\
\hline Hungary & $\begin{array}{c}(-3.680>-3.000) \\
\mathrm{I}(1)\end{array}$ & $\begin{array}{c}(-5.902>-3.000) \\
\text { stationary }\end{array}$ \\
\hline overall conclusion & $\mathrm{I}(1)$ or $\mathrm{I}(2)$ process & Stationary \\
\hline
\end{tabular}

\section{Current account balances and economic integration (Blanchard, Giavazzi, 2002)}

As Olivier Blanchard wrote in his working paper with Giavazzi ${ }^{12}$, a country borrower must take into account when it wants to borrow, interest rate and the price cuts it will have to make in order to generate revenues to repay the debt in the future. In the case of increased integration Blanchard argues borrower countries will borrow more, and lender countries will lend more. If we define $c a$ as current account balance to national income than ca is defined as:

$$
c a_{t}=\frac{1}{2}\left(1-\left[\frac{Y_{t+1}}{Y_{t}} \frac{1}{R(1+x)} \frac{P_{t+1}}{P_{t}}\right]\right)
$$

So, from the equation above the determinants of the current account balance are: Income the higher is output in the nest period relative to this period the higher will be current account deficit. Second the larger the interest rate the lower will be current account deficit (it will be more costly to borrow). Third, The larger the fall in the price of the domestic good required next period to sell domestic goods and repay the debt, the more expensive it is to borrow, the lower the current account deficit.

$$
(C a / Y)_{i t}=\alpha_{t}+b_{t}\left(\frac{Y / N_{i t}}{Y / N_{t}}\right)+X_{i t} \beta+\varepsilon_{i t}
$$

\footnotetext{
${ }^{12}$ Blanchard, Giavazzi, (2002), Current Account Deficits in the Euro Area. The End of the Feldstein Horioka Puzzle?,Working paper
} 
Table 7 Panel between effects linear model (whole sample) $)^{13}$

\begin{tabular}{|l|l|c|c|}
\hline Dependent variable & Current account balance & Coef. & p-value \\
\hline \multirow{2}{*}{ Independent variables } & Income per capita & 0.069965 & 0.012 \\
\cline { 2 - 4 } & Constant & -15.7449 & 0.000 \\
\hline Number of observations & \multicolumn{2}{|c|}{283} \\
\hline Number of groups (panels) & \multicolumn{2}{|c|}{0.4043} \\
\hline$R^{2}$ (between panels) & \multicolumn{2}{|c|}{} \\
\hline
\end{tabular}

$$
\begin{array}{r}
C a / G D P=-15.75+0.069 Y / N \\
\text { P-value }=0.000 \quad \text { P-value }=0.012
\end{array}
$$

As expected the coefficient on the income per capita is positive and statistically significant. In the next Table we introduce the same regression but for the EU members between CEE countries 8 countries ${ }^{14}$.

Table 8 Panel between effects linear model -EU members ${ }^{15}$

\begin{tabular}{|l|l|c|c|}
\hline Dependent variable & Current account balance & Coef. & p-value \\
\hline \multirow{2}{*}{ Independent variables } & Income per capita & 0.029145 & 0.043 \\
\cline { 2 - 4 } & Constant & -9.72245 & 0.000 \\
\hline Number of observations & \multicolumn{2}{|c|}{152} \\
\hline Number of groups (panels) & \multicolumn{2}{|c|}{0.3573} \\
\hline$R^{2}$ (between panels) & \multicolumn{2}{|c|}{} \\
\hline
\end{tabular}

$$
\begin{array}{r}
\text { Second subsample: } C a / G D P=-9.72+0.029 Y / N \\
\text { P-value }=0.000 \quad \text { P-value }=0.043
\end{array}
$$

Here we can see that he difference from the whole sample model is that the coefficients are smaller in size, while the signs are the same. In the next table we present the same model for Non-EU members from CEE countries.

\footnotetext{
${ }^{13}$ See Appendix 4 Between effects panel estimation current account balance on income per capita

${ }^{14}$ Bulgaria, Greece, Hungary, Latvia, Lithuania, Estonia, Poland, Romania

${ }^{15}$ See Appendix 5 Panel between effects linear model -EU members
} 
Table 9 Panel between effects linear model NON-EU members ${ }^{16}$

\begin{tabular}{|l|l|c|c|}
\hline Dependent variable & Current account balance & Coef. & p-value \\
\hline \multirow{2}{*}{ Independent variables } & Income per capita & 0.13546 & 0.000 \\
\cline { 2 - 4 } & Constant & -25.3208 & 0.000 \\
\hline Number of observations & & \multicolumn{2}{|c|}{131} \\
\hline Number of groups (panels) & \multicolumn{2}{|c|}{0.9313} \\
\hline$R^{2}$ (between panels) & \multicolumn{2}{|c|}{} \\
\hline
\end{tabular}

Third subsample: $C a / G D P=-25.32+0.136 Y / N$

$$
\text { P-value }=0.000 \quad P \text {-value }=0.000
$$

So on average in the three subsamples we find positive relationship between current account balance and income per capita but this relationship is of bigger size in non-EU members of CEE countries ${ }^{17}$.The difference is not very significant because these countries have similar current account balances and income per capita when clustered together.

\section{Conclusion (Resume)}

In our paper when we investigate the whole sample fo $14 \mathrm{CEE}$ countries we find less positive association between investment and savings meaning that capital is highly mobile. While when we regress the subsample of those countries from the sample which are EU members we find the lowest coeffcient of association between investment and saving therefore capital is highly mobile in those countries. While in the Non-EU members from this CEE countires the coeficient is highest 0.13 , meaning there is lowest capital mobility. Unit root tests proved that in this sample of countries savings are $\mathrm{I}(1)$ or $\mathrm{I}(2)$ process, and investments are stationary.

\footnotetext{
${ }^{16}$ See Appendix 6

${ }^{17}$ Albania, Bosnia and Herzegovina, Croatia, Kosovo, Macedonia, Serbia
} 
Appendix 0 Six plots for domestic investment and savings

\section{Sixplot for investmenttogdpratio}
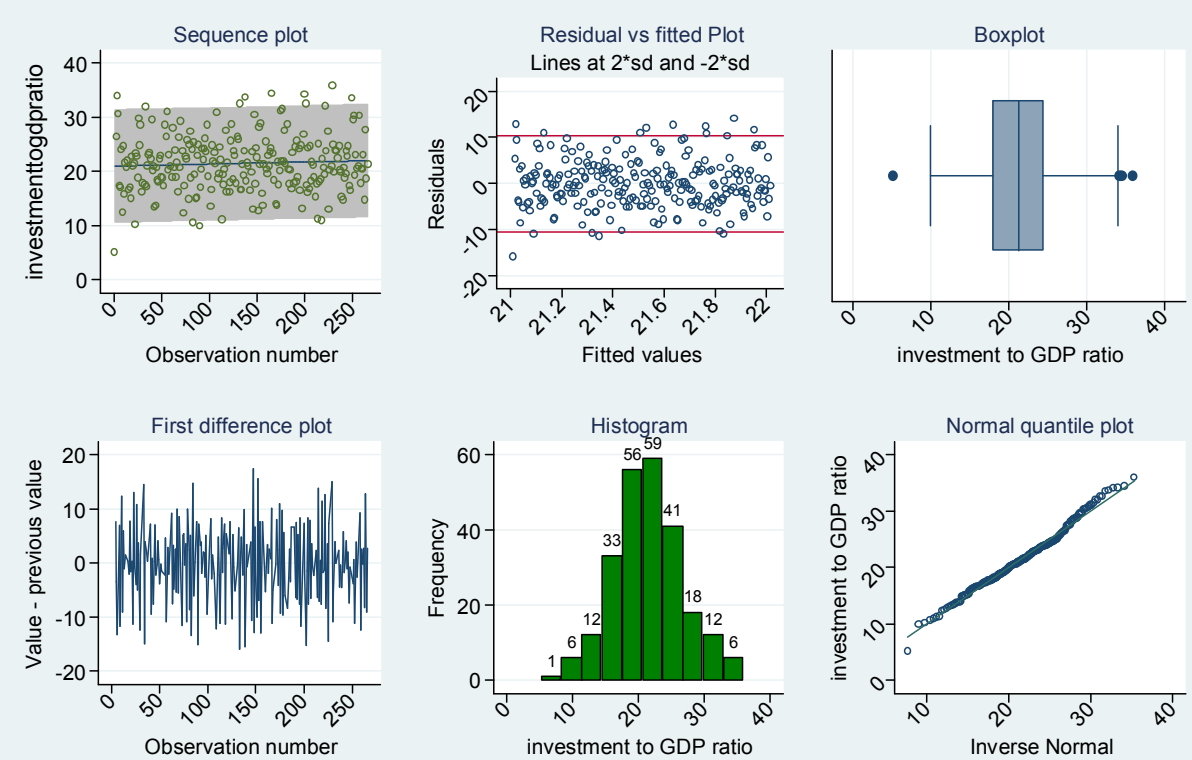


\section{Sixplot for savingstogdp}
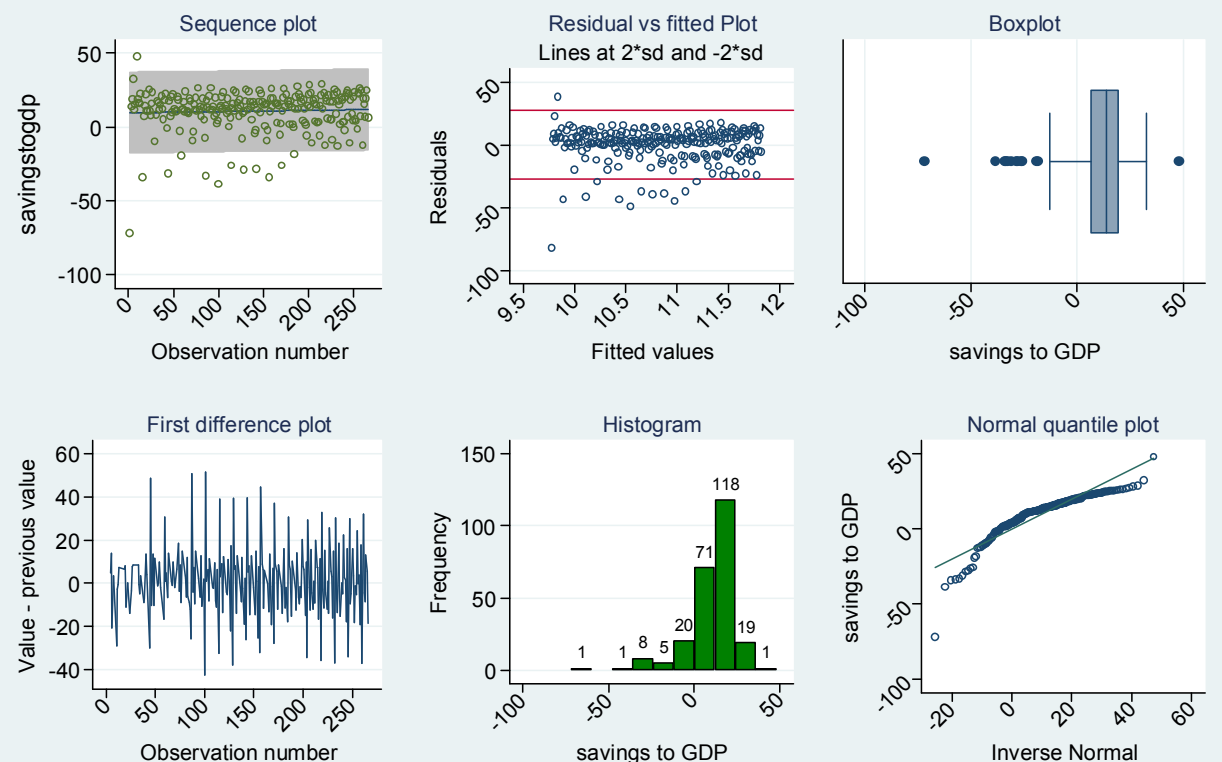
Appendix 1 Definitions of the variables

Interest rate spread

Current

account

domestic

domestic balance

savings

investment is the interest rate charged by banks on loans to prime customers minus the interest rate paid by commercial or similar banks for demand, time, or savings deposits. Current account balance is the sum of net exports of goods,

services, net income, and net current transfers

Gross domestic savings are calculated as GDP less final consumption expenditure (total consumption).

Gross fixed capital formation (formerly gross domestic fixed investment) includes land improvements (fences, ditches, drains, and so on); plant, machinery,

and equipment purchases; and the construction of roads, railways, and the like, including schools, offices, hospitals, private residential dwellings,

and commercial and industrial buildings. According to the 1993 SNA, net acquisitions of valuables are also considered capital formation. 
Appendix 2 Feldstein Horioka Panel regression

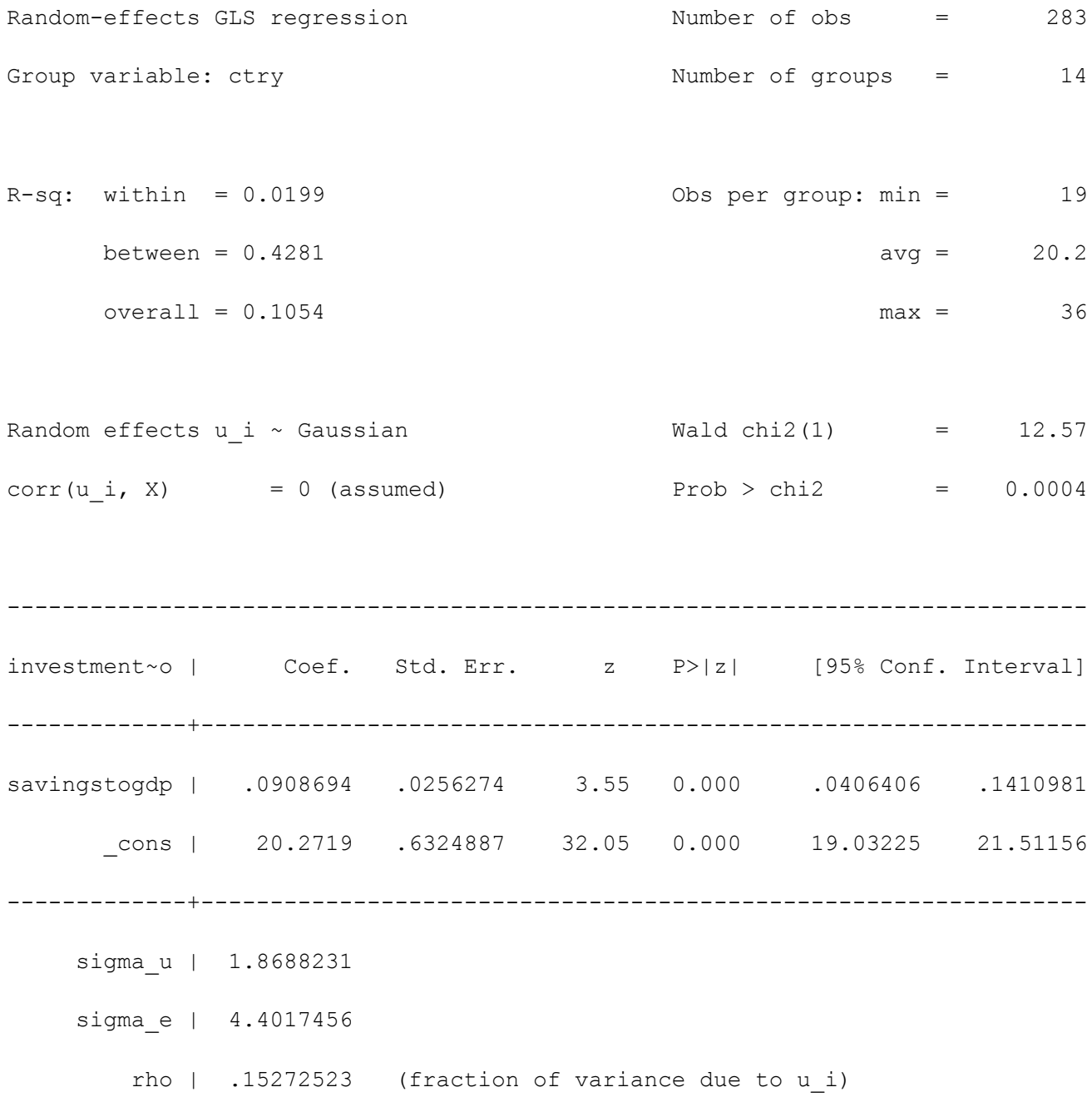


Appendix 3

Feldstein-Horioka regression for CEE countries

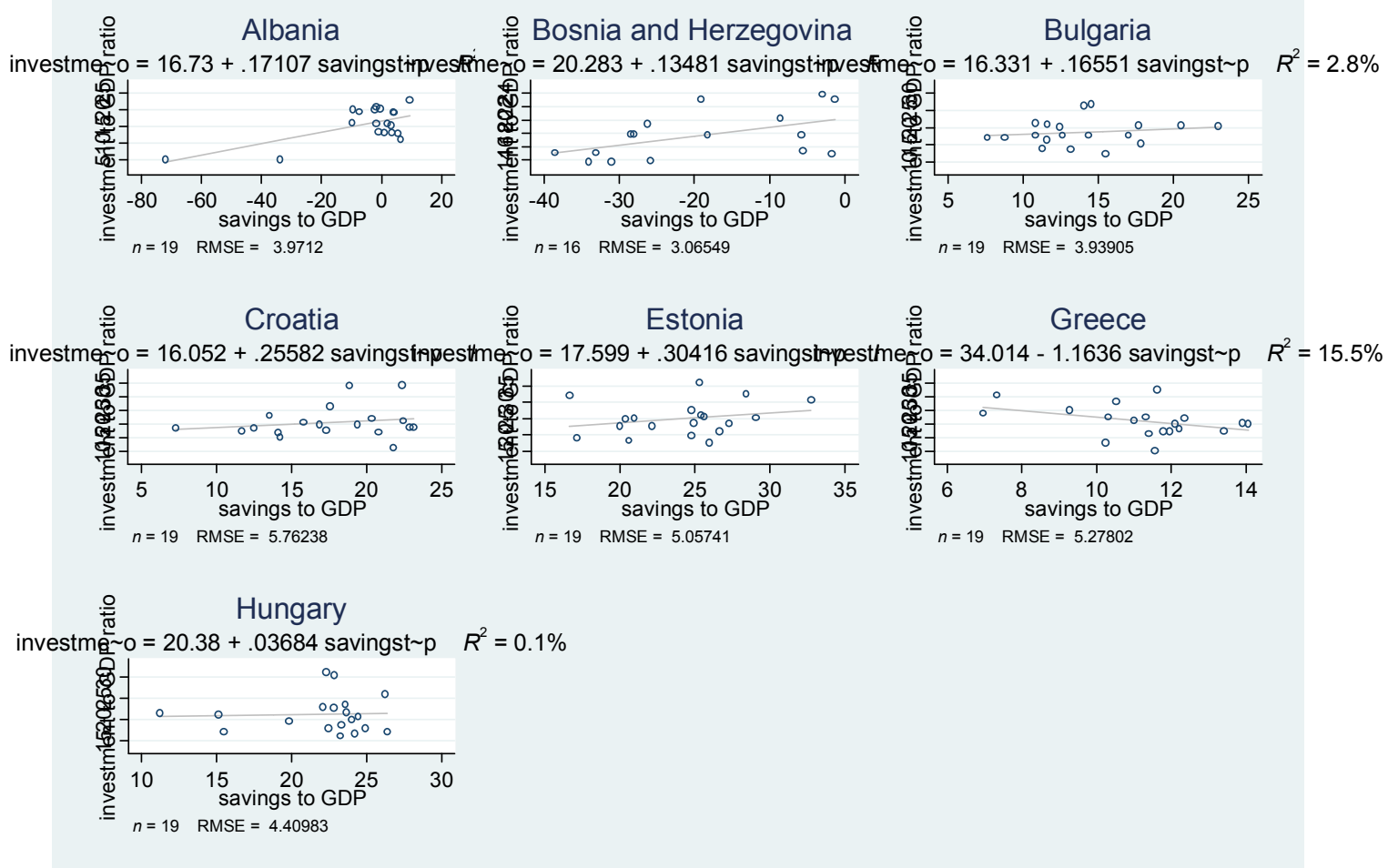




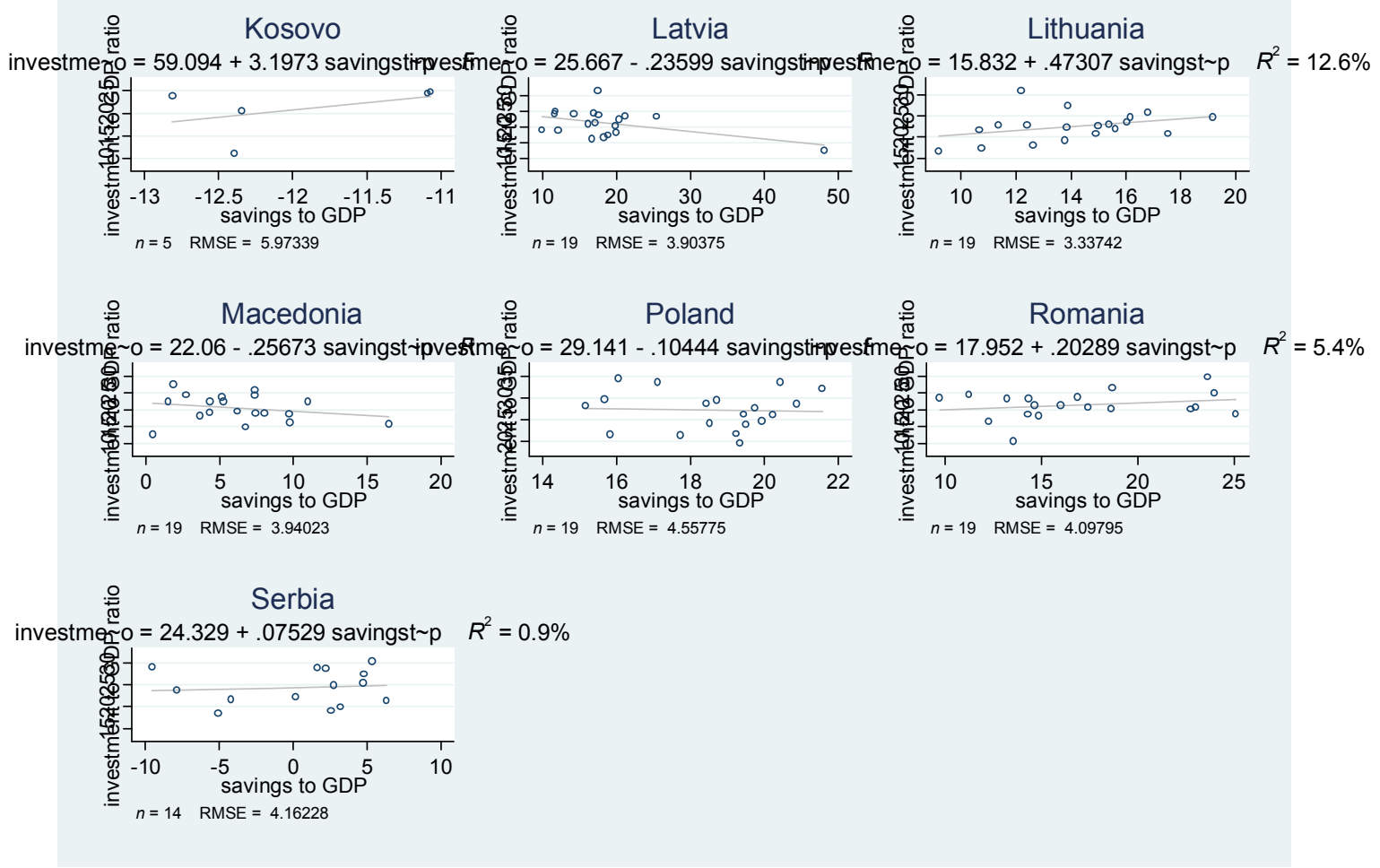


Appendix 4 between effects panel estimation current account balance on income per capita (running xtreg on estimation sample)

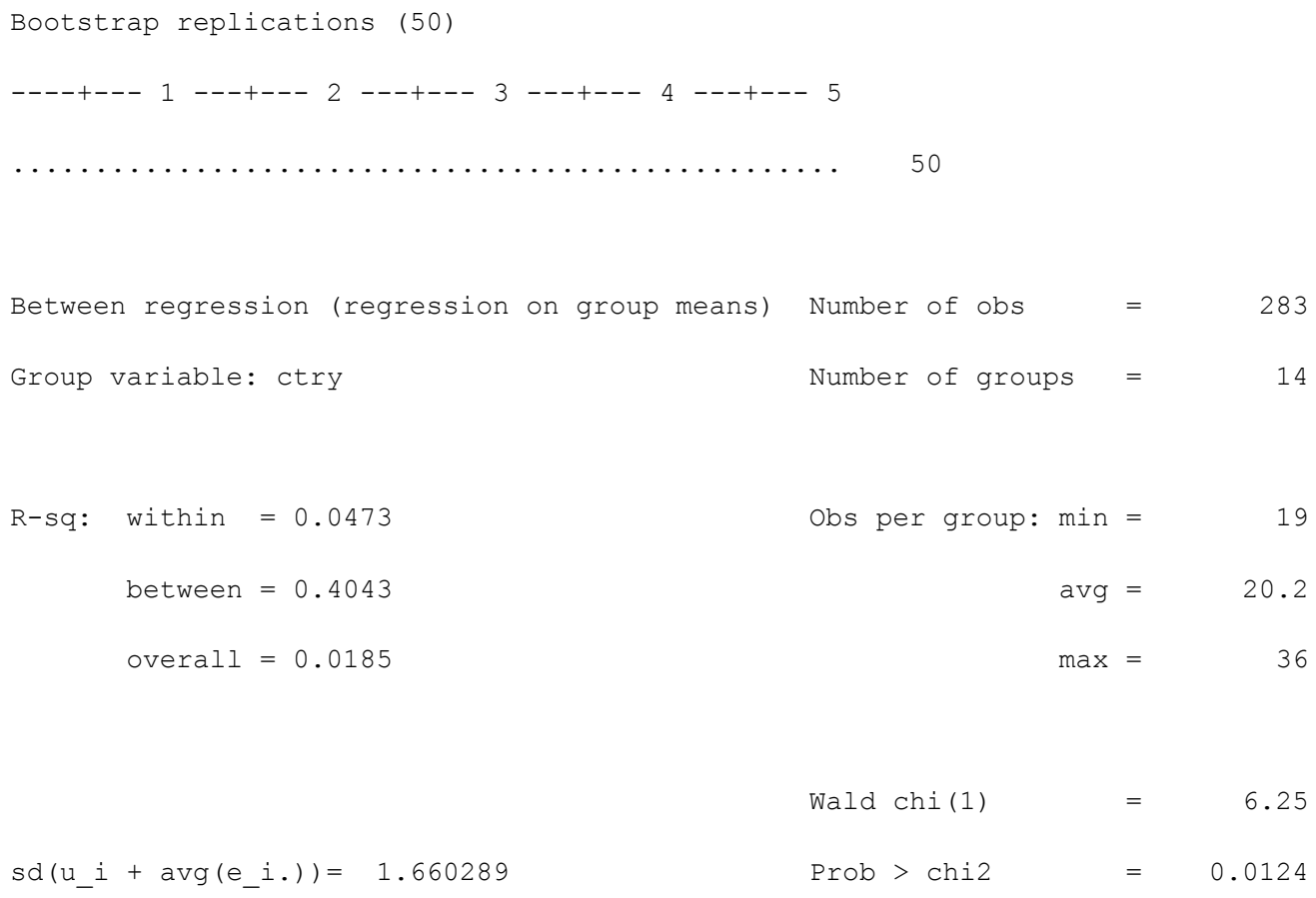

\begin{tabular}{|c|c|c|c|c|c|c|c|}
\hline & । & Observed & Bstrap * & & & & \\
\hline currentacc e & । & Coef. & Std. Err. & z & $\mathrm{P}>|\mathrm{z}|$ & [95\% Conf. & Interval] \\
\hline incomeperc a & । & .0699652 & .0279821 & 2.50 & 0.012 & .0151212 & .1248091 \\
\hline _cons & । & -15.74487 & 3.829871 & -4.11 & 0.000 & -23.25128 & -8.238465 \\
\hline
\end{tabular}


Appendix 5 between effects panel estimation-EU members

(running xtreg on estimation sample)

Bootstrap replications (50)

----+--- 1 ---+--- 2 ---+--- 3 ---+--- 4 ---+--- 5

50

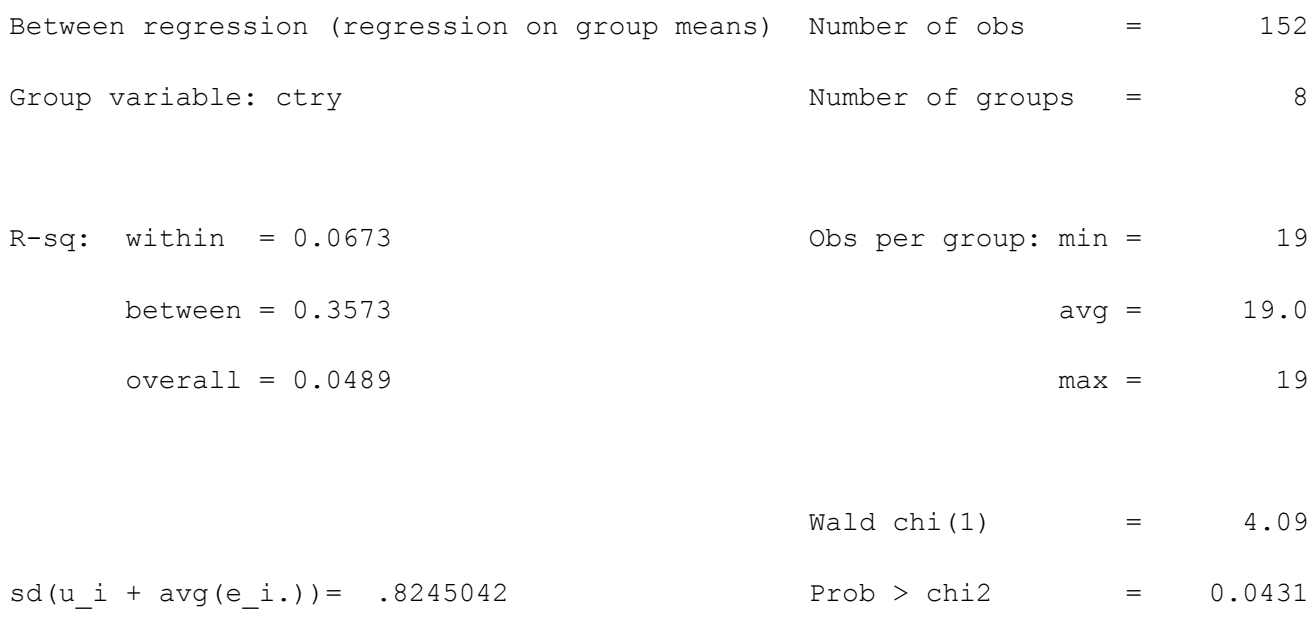

(Replications based on 8 clusters in ctry)

\begin{tabular}{|c|c|c|c|c|c|c|c|}
\hline & । & Observed & Bstrap * & & & & \\
\hline currentacc e & । & Coef. & Std. Err. & $\mathrm{z}$ & $\mathrm{P}>|\mathrm{z}|$ & [95\% Conf. & Interval] \\
\hline incomeperc a & । & .0291447 & .0144116 & 2.02 & 0.043 & .0008986 & .0573909 \\
\hline _cons & । & -9.722447 & 1.603641 & -6.06 & 0.000 & -12.86553 & -6.579367 \\
\hline
\end{tabular}


Appendix 6 between effects panel estimation-NON EU members

(running xtreg on estimation sample)

Bootstrap replications (50)

----+--- 1 ---+--- 2 ---+--- 3 ---+--- 4 ---+--- 5

50

Between regression (regression on group means) Number of obs $=131$

Group variable: ctry $\quad$ Number of groups $=6$

R-sq: within $=0.0302 \quad$ Obs per group: $\min =\quad 19$

between $=0.9313 \quad$ avg $=\quad 21.8$

overall $=0.0005 \quad \max =\quad 36$

sd $\left(u_{-} i+\operatorname{avg}\left(e_{-}{ }.\right)\right)=.8019493 \quad$ Prob $>$ chi2 $\quad 0.0000$

(Replications based on 6 clusters in ctry)

\begin{tabular}{|c|c|c|c|c|c|c|c|}
\hline & । & Observed & Bstrap * & & & & \\
\hline currentacc e & । & Coef. & Std. Err. & $\mathrm{z}$ & $P>|z|$ & [95\% Conf. & Interval] \\
\hline incomeperc a & । & .1354603 & .032697 & 4.14 & 0.000 & .0713755 & .1995452 \\
\hline _cons & । & -25.32076 & 4.435219 & -5.71 & 0.000 & -34.01363 & -16.62789 \\
\hline
\end{tabular}


[1]. Blanchard, Giavazzi, (2002), Current Account Deficits in the Euro Area. The End of the Feldstein Horioka Puzzle?,Working paper

[2]. Chen, H.(2007), Macroeconomic Conditions and the Puzzles of Credit Spreads and Capital Structure, University of Chicago GSB

[3]. Coakley,Farida Kulasi, and Ron Smith(1998), The Feldstein-Horioka Puzzle and Capital Mobility: A Review, International Journal of Finance and Economics Int. J. Fin. Econ. 3: 169-188 (1998)

[4]. Feldstein, Martin; Horioka, Charles (1980), "Domestic Saving and International Capital Flows", Economic Journal (The Economic Journal, Vol. 90, No. 358$) 90$ (358): 314-329,

[5]. Frankel, J.A., 'Measuring International Capital Mobility-A Review', American Economic Review, 82 (1992),197-202.

Horioka puzzle for Australia, Department of Business Economics, Auckland University of Technology, New Zealand, Department of Economics, University of the West of England, Bristol, UK

[6]. Kevin Grier, Shu Lin.Haichun Ye,(2008), Savings and Investment in the USA: Solving the Feldstein Horioka Puzzle, University of Colorado Denver

[7]. Krol, H., 'International Capital Mobility: Evidence from Panel Data' Journal of International Money and Finance, 15 (1996), 467-74.

[8]. Kumar , S. Fargher,S., Webber,D.(2010), Testing the validity of the Feldstein-

[9]. Obstfeld, M. and Rogoff, K., 'The Intertemporal Approach to the Current Account', in G.M. Grossman and K. Rogoff (Eds.), op.cit., 1995, 1731-99.

[10]. Özmen,E, (2004), Financial Development, Exchange Rate Regimes and the Feldstein-Horioka Puzzle: Evidence from the MENA Region, ERC Working Papers in Economics 04/18 